PYTHAGORAS: Jurnal Pendidikan Matematika

Volume 11 - Nomor 2, Desember 2016, (169-181)

Available online at: http://journal.uny.ac.id/index.php/pythagoras

\title{
Pengembangan Tes Kemampuan Pemecahan Masalah dan Penalaran Matematika Siswa SMP Kelas VIII
}

\author{
Nurul Afni Sinaga \\ Universitas Negeri Medan. Jalan William Iskandar Pasar V, Deli Serdang, 20222, Indonesia \\ Korespondensi Penulis. Email: nurulafnisinaga7@gmail.com
}

\begin{abstract}
Abstrak
Penelitian ini bertujuan untuk menghasilkan perangkat tes kemampuan pemecahan masalah dan penalaran matematika siswa SMP kelas VIII yang valid dan memiliki karakteristik yang baik. Penelitian ini merupakan penelitian pengembangan yang mengembangkan tes kemampuan pemecahan masalah dan penalaran SMP kelas VIII. Uji coba lapangan dilakukan di tiga sekolah SMP Negeri di Yogyakarta yaitu SMP Negeri I Yogyakarta, SMP Negeri 6 Yogyakarta dan SMP Negeri 14 Yogyakarta. Analisis data dilakukan dengan mengkonversi total skor aktual yang diperoleh menjadi data kualitatif skala lima untuk memperoleh kevalidan dan telaah butir soal secara kuantitatif melalui teori tes klasik (Clasiccal Test Theory) dan teori respons butir (Item Respone Theory) menggunakan model rasch dengan program QUEST. Hasil validasi isi menunjukkan bahwa perangkat yang dikembangkan memiliki kategori valid. Karakteristik dari tes yang dikembangkan juga memiliki karakteristik yang baik, ditinjau dari tingkat kesulitan tes berada pada kategori sedang dan memiliki daya beda cukup memuaskan. Secara keseluruhan, hasil penelitian menunjukkan bahwa perangkat tes yang dikembangkan adalah layak untuk digunakan.
\end{abstract}

Kata Kunci: pengembangan tes, pemecahan masalah, penalaran

\section{Development of Problem Solving Ability and Mathematical Reasoning Test of Junior High School Students Class VIII}

\begin{abstract}
This research's aim was to produce the kit for problem solving ability and mathematical reasoning test of JHS student class VIII which valid and has a good characteristic. This research was a development research which develop problem solving ability and reasoning test of JHS class VIII. Field trial was performed in three JHS in Yogyakarta namely JHS State I Yogyakarta, JHS State 6 Yogyakarta and JHS State 14 Yogyakarta. Data analysis was performed by converting the total collected actual score into five scales qualitative data to derive validity and study on question items quantitatively through classical test theory and item respone theory was using Rasch model with QUEST program. Content Validaty result suggested that this developed test kit has a valid category. Characteristic of the developed test kit was also has a good characteristic, reviewed from the test difficulty level it was in medium category and has a quite satisfying different power. Overall, the research result suggested that the developed test kit was feasible to use.
\end{abstract}

Keywords: test development, problem solving, reasoning

How to Cite: Sinaga, N. (2016). Pengembangan tes kemampuan pemecahan masalah dan penalaran matematika siswa SMP kelas VIII. PYTHAGORAS: Jurnal Pendidikan Matematika, 11(2), 169-181. doi:http://dx.doi.org/10.21831/pg.v11i2.10642

Permalink/DOI: http://dx.doi.org/10.21831/pg.v11i2.10642 


\section{PENDAHULUAN}

Perkembangan ilmu pengetahuan dan teknologi dari waktu ke waktu semakin pesat. Perkembangan ini tidak terlepas dari peranan dunia pendidikan, karena melalui pendidikanlah seseorang dipersiapkan menjadi generasi yang sanggup menghadapi tantangan baru yang akan datang. Kemajuan ilmu pengetahuan dan teknologi menuntut seseorang untuk dapat menguasai informasi dan pengetahuan yang ada (Herman, 2007, p.41) sehingga diperlukan suatu kemampuan memperoleh, memilih, dan mengelola informasi. Kemampuan-kemampuan tersebut harus didasari oleh pemikiran yang kritis, sistematis, dan logis, karena kemampuan tersebut sangat penting dalam menganalisa, mengevaluasi segala argumen untuk mampu membuat keputusan yang rasional dan bertanggung jawab. Oleh karena itu diperlukan suatu program pendidikan yang dapat mengembangkan kemampuan berpikir kritis, sistematis dan logis. Salah satu program pendidikan yang dapat mengembangkan kemampuan tersebut adalah matematika.

Melihat pentingnya matematika dan peranannya dalam menghadapi kemajuan ilmu pengetahuan dan teknologi serta persaingan global maka peningkatan mutu pendidikan matematika di semua jenis dan jenjang pendidikan harus selalu diupayakan. Salah satu upaya yang dapat dilakukan adalah dengan menyempurnakan kurikulum pendidikan. Pada Kurikulum Tingkat Satuan Pendidikan (KTSP), tujuan yang ingin dicapai melalui pembelajaran matematika di jenjang SMP adalah (1) memahami konsep matematika, menjelaskan keterkaitan antar konsep dan mengaplikasikan konsep atau algoritma, secara luwes, akurat, efisien, dan tepat, dalam pemecahan masalah; (2) menggunakan penalaran pada pola dan sifat, melakukan manipulasi matematika dalam membuat generalisasi, menyusun bukti, atau menjelaskan gagasan dan pernyataan matematika; (3) memecahkan masalah yang meliputi kemampuan memahami masalah, merancang model matematika, menyelesaikan model dan menafsirkan solusi yang diperoleh; (4) mengomunikasikan gagasan dengan simbol, tabel, diagram, atau media lain untuk memperjelas keadaan atau masalah; (5) memiliki sikap menghargai kegunaan matematika dalam kehidupan, yaitu memiliki rasa ingin tahu, perhatian, dan minat dalam mempelajari matematika, serta sikap ulet dan percaya diri dalam pemecahan masalah. (Depdiknas, 2006, p. 346).

Berdasarkan tujuan tersebut, setidaknya terdapat beberapa kompetensi yang diharapkan dimiliki oleh siswa setelah mempelajari matematika, diantaranya: (1) memecahkan masalah yang meliputi kemampuan memahami masalah, merancang model matematika, menyelesaikan model dan menafsirkan solusi yang diperoleh dan menggunakan penalaran pada pola dan sifat; (2) melakukan manipulasi matematika dalam membuat generalisasi, menyusun bukti, serta mampu mengkomunikasikan gagasan atau ideide matematika.

Namun kenyataanya, prestasi siswa di Indonesia dalam bidang matematika tergolong rendah. Rendahnya prestasi dalam belajar matematika dapat diketahui dari hasil studi internasional tentang prestasi siswa. Survei Trends International Mathematics and Science Study (TIMSS) menempatkan Indonesia pada peringkat 34 dari 45 negara pada tahun 2003. Skor yang dicapai masih dibawah rata-rata untuk wilayah ASEAN dimana skor yang didapat Indonesia sebesar 411. Untuk survei Programme for International Student Assessment (PISA), yang mengukur kemampuan anak usia 15 tahun dalam literasi membaca, matematika, dan ilmu pengetahuan, pada tahun 2003 menempatkan Indonesia pada peringkat 2 terendah dari 40 negara. Indonesia mengikuti TIMSS pada tahun 1999, 2003 dan 2007, 2011 dan PISA tahun 2000, 2003, 2006, 2009 dengan hasil tidak menunjukkan banyak perubahan pada setiap keikutsertaan. PISA tahun 2009 Indonesia menduduki rangking 61 dari 65 peserta dengan rata-rata skor 371 , sementara rata-rata skor internasional adalah 496. Prestasi pada TIMSS 2011 untuk siswa kelas VIII menurun menjadi 386, dibanding tahun 2007 yaitu 405. Rangking Indonesia pada TIMSS tahun 2011 menjadi rangking 38 dari 45 negara. Rendahnya hasil TIMSS dan PISA dari siswa Indonesia pada bidang studi matematika ada kemungkinan dikarenakan rendahnya kemampuan pemecahan masalah dan penalaran matematis siswa.

Rendahnya capaian siswa Indonesia dalam penalaran terlihat juga pada hasil studi TIMSS pada domain konten materi dan domian kognitif pada mata pelajaran matematika khususnya di SMP yang diberikan pada kegiatan pembelajaran sehari-hari. Kemampuan rata-rata siswa Indonesia pada tiap domain masih jauh di bawah negara tetangga Malaysia, Thailand dan Singapura. Rata-rata persentase yang paling 
rendah yang dicapai oleh siswa Indonesia adalah pada domain kognitif pada level penalaran (reasoning) yaitu 17\%. Rendahnya kemampuan matematika siswa pada domain penalaran dapat dijadikan cermin bahwa kemampuan penalaran siswa di Indonesia perlu mendapat perhatian yang lebih serius.

Menurut Solso (2004, p.44) seorang pakar psikologi menjelaskan bagaimana proses kognisi pada manusia dimana ia menyatakan bahwa "it is believed that human cognition takes place in the large patterns of neural activity that are distributed throught out the brain, function in parallel, and operate by means of excitatory or inhibitory connections".

Pernyataan tersebut menjelaskan bahwa proses kognisi manusia terjadi di pola-pola besar aktivitas neural yang terdistribusi di seluruh otak, yang berfungsi secara paralel, dan beroperasi melalui koneksi eksitatoris \& inhibitoris. Menurut hal tersebut dapat dikatakan bahwa otak merupakan pusat berpikir dan kognisi manusia dimana disitulah letak seorang manusia mampu mengembangkan bernalarnya serta memecahkan suatu masalah. Oleh karena itu sudah selayaknya bahwa kemampuan pemecahan masalah dan penalaran matematis mendapatkan perhatian yang sangat khusus dalam pembelajaran matematika. Apabila kelemahan semacam ini tidak diantisipasi dan tidak diperbaiki maka akan selalu terjadi dan akan menghambat pada pencapaian tujuan pembelajaran matematika.

Antisipasi yang dapat dilakukan terkait dengan kelemahan siswa dalam kemampuan pemecahan masalah dan penalaran adalah dengan memperbaiki kualitas pendidikan dengan membuat sistem pengukuran yang baik. Kualitas pendidikan tidak dapat dilepaskan dari prosedur evaluasi berupa pengukuran kemampuan karena pengukuran merupakan salah satu dari sekian faktor dalam sistem yang sangat menentukan keberhasilan pendidikan. Seorang guru sangatlah penting memahami prosedur pengukuran karena seorang guru akan mudah menilai sejauh mana tingkat pemahaman dan penguasaan siswa terhadap materi pelajaran, bahkan dengan mudah dapat dihimpun informasi sampai sejauh mana siswa mampu mengaplikasikan, mensintesa dan menganalisis materi yang diajarkan oleh guru.

Mengukur kemampuan siswa secara akurat sangatlah penting karena guru tidak dapat membantu siswa secara efektif jika tidak mengetahui pengetahuan dan keterampilan yang dikuasai siswa dan mata pelajaran apa yang menjadi masalah bagi siswa. Mengukur kemampuan khususnya kemampuan pemecahan masalah dan penalaran siswa dapat dilakukan dengan berbagai cara salah satunya dengan memberikan tes. Tes adalah suatu perangkat yang sengaja disusun untuk mengukur sesuatu yang pengerjaannya tergantung dari petunjuk yang diberikan.

Instrumen pengukuran dalam bentuk tes yang kurang cermat akan memberikan hasil yang kurang cermat pula, sebaliknya teknikteknik penyusunan tes yang tepat dapat diharapkan memberikan landasan yang kokoh untuk melakukan evaluasi yang tepat. Hasil pengukuran yang diperoleh harus mempunyai kesalahan sekecil mungkin, tingkat kesalahan ini erat kaitannya dengan alat ukur yang dipakai. Mardapi (2007, p.3) menyebutkan kesalahan pengukuran ada yang bersifat acak dan ada yang bersifat sistematik. Kesalahan acak disebabkan kondisi fisik dan mental yang diukur dan yang mengukur bervariasi, sedangkan kesalahan sistematik bisa disebabkan oleh alat ukurnya.

Kenyataannya penyusunan tes yang dilakukan oleh guru untuk mengetahui kemampuan siswa belum memenuhi syarat pengembangan tes yang baik. Pengembangan tes yang dilakukan oleh guru belum dianalisa secara benar dan akurat apakah tes tersebut benar dapat mengukur kemampuan tertentu. Fakta tersebut diperoleh dari observasi kepada beberapa guru sekolah. Perangkat tes yang digunakan guru-guru tersebut merupakan buatan masing-masing pengampu mata pelajaran, demikian pula mata pelajaran matematika. Pembuatan perangkat tes tersebut tidak mengikuti langkah-langkah pembuatan tes yang telah ada, misalnya tidak diawali dengan pembuatan kisi-kisi soal dan tidak diketahui karakteristik masing-masing butirnya karena tidak dianalisis, baik secara teoritik maupun secara empirik. Umumnya ketika seorang guru ingin memberikan tes ulangan semester ataupun kenaikan kelas terhadap siswa, guru tersebut membuat sendiri dan/atau memilih beberapa soal dari buku paket yang sesuai dengan kompetensi yang akan dicapai siswa. Hal ini disebabkan karena guru kesulitan dalam membuat/ menyajikan soal yang bervariasi, lambat dalam pembuatan serta kurangnya waktu untuk melakukan analisa empirik.

Melalui pengembangan perangkat tes kemampuan pemecahan masalah dan penalaran matematika diharapkan dapat dijadikan sebagai salah satu sarana bagi guru untuk dapat 
menyelesaikan permasalahan tersebut. Informasi yang terdapat dalam perangkat tes yang dikembangkan serta butir-butir soal akan sangat membantu dalam pengembangan tes lainnya. Informasi yang ada membantu dalam menyeleksi dan menetapkan butir soal mana yang dipilih jika akan menyusu tes dengan karakteristik tertentu. Hal ini akan meningkatkan kualitas tes dan hasil pengukuran karena tes yang disusun sesuai dengan tingkat kemampuan siswa sehingga informasi hasil tes menjadi tinggi. Informasi hasil pengukuran yang tinggi akan membantu dalam pengambilan kebijakan yang tepat.

Instrumen atau alat ukur menjadi faktor yang sangat penting dalam penelitian pendidikan. Menurut Purwanto (2007, p.99), instrumen merupakan alat bantu yang digunakan oleh peneliti untuk mengumpulkan data dengan cara melakukan pengukuran. Oleh karena instrumen menjadi alat pengumpul data, maka instrumen haruslah dibuat dengan baik dan mampu mengumpulkan data yang sesuai dengan kebutuhan suatu penelitian. Gronlund \& Linn (1990, p.79) menyatakan bahwa "the most esential of these characteristics can be classified under the headings of validity, reliability an usability". Karakteristik utama yang harus dimiliki oleh sebuah alat ukur dapat diklasifikasikan menjadi karakter validitas, reliabilitas dan tingkat kegunaannya.

Pengembangan instrumen yang baik menjadi bagian yang sangat penting dalam penilaian dan evaluasi karena penilaian dalam dunia pendidikan menjadi salah satu bagian penting dalam meningkatkan kualitas pendidikan. Reynolds, Cecil, \& Livingston (2009, p.20) menyatakan bahwa "educational assessments also can provide important information that helps teachers adjust and enhance their teaching practices. For example, assessment information can help teacher determine what to teach, how to teach it, and how effective their instruction has been".

Pendapat ini menyatakan penilaian dalam pendidikan dapat memberikan informasi yang penting yang dapat membantu guru memahami dan meningkatkan kegiatan belajar mengajar mereka. Sebagai contoh, informasi hasil penilaian dapat membantu guru menentukan apa yang akan diajarkan, bagaimana mengajarkannya, dan seberapa efektif pembelajaran yang dilakukan.

Membicarakan pengembangan instrumen tidak akan terlepas dengan pengukuran. Alat ukur tes ini bertujuan untuk memperoleh skor melalui prosedur yang bersangkutan. Melalui pengukuran akan dibahas klasifikasi teori pengukuran yang digunakan untuk menunjukkan bukti kualitas suatu tes. Measurement (Pengukuran) dalam teori tes menurut Weitzenhoffer adalah pemberian angka pada objek atau peristiwa menurut aturan (Crocker \& Algina, 1986, p.3). Sejalan dengan pandangan bahwa pengukuran seharusnya didefinisikan sebagai upaya mengangkakan objek dan peristiwa menurut aturan logika yang bisa diterima, (Guilford, 1936, pp.1-2), Nunnaly (1978, p.3) menyatakan "measurement consists of rules for assigning numbers to objects in such a way as to represent quantities of attributes". Pengukuran terdiri dari aturan pemberian angka sedemikian rupa sehingga mempresentasikan kuantitas dari atribut.

Pengukuran kemampuan siswa sangat penting agar diketahui bagaimana kemampuan matematika siswa. Kemampuan yang penting untuk diukur diantaranya adalah kemampuan pemecahan masalah. Penjelasan tentang pemecahan masalah tidak terlepas dengan apa itu sebenarnya masalah.

Lester (1980, p.287) menyatakan bahwa masalah adalah "a situation in which individual or grup is called to perform a task for which there is no ready accessible algorithm which determaine completely the methods of solution". Masalah adalah suatu situasi dimana seorang individu atau kelompok disebut terbuka untuk melakukan suatu tugas untuk hal mana tidak ada algoritma yang siap yang dapat diterima sebagai suatu metode pemecahannya. Jika jawaban suatu masalah telah diperoleh maka hal itu tidak lagi disebut masalah. Mayer menyatakan definisi masalah (Royer, 2003, p.70) adalah "a problem exists when you have a goal but do not immediatelly know how to reach the goal. Thus, a problem consists of three elements: a given states (i.e., the curent state of the situation), a goal state (i.e., the desired state of the situation), and the obstacles that block you from moving directly from the given state to the goal state".Suatu masalah ada ketika seseorang memiliki sebuah tujuan tetapi tidak dapat segera mengetahui cara untuk mencapai tujuan tersebut, sehingga sebuah masalah terdiri atas tiga elemen, yaitu: sebuah keadaan yang diberikan (situasi tertentu), sebuah keadaan tujuan (keadaan dari situasi yang diinginkan) dan rintangan yang menghalangi seseorang bergerak langsung dari keadaan yang diberikan ke keadaan yang diinginkan. 
Masalah dalam matematika dapat dibagi atas beberapa macam. Polya (2004, p.171) menyatakan bahwa "in general, a problem is a "routine problem" if it can be solved either by substituting special data into a formerly solved general problem, or by following step by step, without any trace of originality, some well-worn conspicuous example". Masalah rutin adalah suatu masalah yang dapat diselesaikan dengan mensubstitusi data khusus kedalam bentuk masalah yang akan diselesaikan tanpa suatu tantangan yang berarti. Sedangkan Clark (2009, p.1) mengatakan "mathematical problem solving is central to mathematics learning. It involves the acquisition and application of mathematics concepts and skills in a wide range of situations, including non-routine, open-ended and realworld problems". Pemecahan masalah matematika adalah pusat dari pembelajaran matematika. Pemecahan masalah ini melibatkan penerimaan dan aplikasi dari konsep dan kemampuan matematika dalam berbagai macam situasi, termasuk non rutine, open ended dan masalah dunia nyata. Oleh karena itu dapat dikatakan bahwa masalah terdiri dari masalah rutin dan masalah tidak rutin. Hal ini sejalan dengan pendapat Sternberg, Ben-Zeev \& Talia (1996, p.32) bahwa masalah matematika terbagi atas masalah rutin dan masalah tidak rutin. Masalah rutin adalah suatu masalah yang semata-mata hanya merupakan latihan yang dapat dipecahkan dengan menggunakan beberapa perintah atau algoritma. Masalah tidak rutin lebih menantang dan memerlukan kemampuan kreativitas dalam mencari solusi pemecahan masalahnya.

Memecahkan masalah diperlukan kemampuan untuk melihat setiap informasi yang dapat digunakan dan menggunakan pengetahuan yang dimilikinya dengan sebaik-baiknya. Pengetahuannya tentang strategi pemecahan masalah memberikan banyak pilihan dalam menentukan langkah-langkah yang akan digunakan untuk memecahkan suatu masalah. Adams \& Hamm (2010, p. 106) menyatakan bahwa "during the course of solving their problem, students are forced to test hypotheses and frequently generate new questions". Selama upaya memecahkan masalah, peserta didik dipakasa untuk menguji hipotesis mereka dan sering kali menimbulkan pertanyaan baru. Kondisi ini akan melibatkan banyak penyelidikan ilmiah dan pemecahan masalah matematika.

Pemecahan masalah telah dikaitkan dengan maksud yang berbeda-beda tetapi memiliki makna yang sama. Schoenfeld (1992, pp.334-
470) mengemukakan tiga pandangan berbeda tentang pemecahan masalah.

There are three traditionally different views of problem solving. In one, problem solving is the act of solving problems as a means to facilitate the achievement of other curricular goals such as teaching mathematics, motivation, recreation, developing and practicing mathematics skills. In another, problem solving is a goal, out of many, in itself of the instructional process. It is a skill or piece of knowledge that is worth teaching in its own right. Finally, when challenging problems are involved, problem solving can be viewed as a form of art, as what mathematics is ultimately all about.

Tiga pandangan yang berbeda terkait dengan pemecahan masalah adalah pertama, pemecahan masalah adalah memecahkan masalah sebagai sarana untuk memfasilitasi pencapaian dari tujuan kurikulum lainnya seperti pembelajaran matematika, motivasi, rekreasi, mengembangkan dan melatih keterampilan matematika. Pandangan kedua, pemecahan masalah adalah tujuan dari banyak orang dimana di dalam dirinya terjadi proses pembelajaran. Hal yang dimaksud adalah pengetahuan seseorang bahwa mengajar ada di dalam dirinya sendiri. Pandangan ketiga ketika melibatkan masalah yang menantang, pemecahan masalah dapat dipandang sebagai bentuk seni, sebagaimana matematika yang menjelaskan tentang semua.

Kemampuan lain yang dibutuhkan siswa dalam pembelajaran matematika adalah kemampuan penalaran. Penalaran adalah suatu proses atau aktivitas berpikir untuk menarik suatu kesimpulan atau proses berpikir dalam rangka membuat suatu pernyataan baru yang benar berdasar pada beberapa pertanyaan yang kebenarannya telah dibuktikan atau diasumsikan sebelumnya. Kaur (2009, p.102) menyatakan bahwa "reasoning is the process of making inferences from a body of information". Penalaran adalah kemampuan untuk menyimpulkan sekumpulan informasi. Keraf (1982, p.5) menyatakan bahwa proses berpikir yang berusaha menghubung-hubungkan fakta-fakta atau evidensi-evidensi yang diketahui menuju kepada suatu kesimpulan. Oleh karena itu penalaran sangat dibutuhkan dalam matematika karena menyelesaikan suatu persoalan matematika harus dengan pemikiran, mengerti dan mampu menemukan sesuatu berdasarkan opini atau 
ketentuan yang sudah ada. Hal ini didukung dengan pernyataan Ball \& Bass (Brodie, 20108, p.8) yang menjelaskan bahwa "reasoning is a "basic skill" of mathematics and necessary for a number of purpose to understand mathematiccal concept, to use mathematical ideas and procedures flexibly, and reconstruct once understood, but forgotten mathematical knowledge. Penalaran merupakan "keterampilan dasar" matematika yang diperlukan untuk beberapa tujuan dalam memahami konsep-konsep matematika, menggunakan ide-ide matematika dan prosedur fleksibel dan mengkontruksi pengetahuan matematika.

Selain itu Reys, et al. (2009, p.96) juga menjelaskan bahwa "reasoning mathematically involves observing patterns, thinking about them, and justifying why they should be true in more than just individual instances". Penalaran matematika meliputi mengamati pola, berpikir tentang pola, dan memberikan alasan mengapa pola itu harus terjadi dalam hanya pada kasus individu. Penalaran pola terjadi pada kasus individu. Penalaran matematika (mathematical reasoning) diperlukan untuk menentukan apakah sebuah argumen matematika benar atau salah dan juga dipakai untuk membangun suatu argumen matematika. Penalaran matematika tidak hanya penting untuk melakukan pembuktian (proof) atau pemeriksaan program (program verification), tetapi juga untuk melakukan inferensi dalam suatu sistem kecerdasan buatan (artificial intellegence).

Barbey \& Barsalao (2009, p.35) menyatakan bahwa "reasoning is a hallmark of human thought, supporting the process of discovery that leads from what is known or hypothesized, to what is unknown or implicit in one's thinking". Penalaran merupakan ciri dari pemikiran manusia, mendukung proses penemuan yang mengarah dari apa yang diketahui atau diduga, apa yang tidak diketahui atau implisit dalam pemikiran seseorang.

Oleh karena itu dapatlah dikatakan bahwa penalaran adalah proses berpikir yang mencakup berpikir dasar, berpikir kritis dan berpikir kreatif, tetapi tidak termasuk mengingat (recall). Pengembangan penalaran merupakan suatu aspek penting karena dapat digunakan dalam menyelesaikan masalah-masalah lain, baik masalah matematika maupun masalah seharihari. Untuk aspek pemecahan masalah sangat diperlukan atau melibatkan penalaran dalam menyelesaikan masalah agar masalah tersebut dapat terpecahkan dan mendapatkan solusi.
Penalaran adalah aspek yang dibutuhkan dalam memecahkan suatu masalah khususnya permasalahan matematika.

Haylock \& Thangata (2007, pp.52-53) menjelaskan bahwa:

There are two kinds of reasoning that feature prominently in doping mathematics. Inductive reasoning is the kind of thinking involved in recognizing patterns, similiarities nd equivalences, and using these to predict further result and to formulate generalizations. Deductive reasoning is the formulation af a valid, logical argument to explain, demonstrate or convince others that solution to a problem must be correct, or that a mathematical theorem is proved beyond doubt, or that a particular conjecture is true or false".

Terdapat dua macam penalaran yang sering digunakan dalam mempelajari matematika, yaitu penalaran induktif dan penalaran deduktif. Kesimpulan yang bersifat umum yang dapat ditarik dari kasus-kasus yang bersifat individual dikenal dengan penalaran induktif. Sebaliknya, penalaran yang bermuara dari hal yang bersifat umum ke kasus yang bersifat individual dikenal sebagai penalaran deduktif. Penalaran matematis penting untuk mengetahui dan mengerjakan persoalan matematika. Kemampuan untuk bernalar menjadikan peserta didik dapat memecahkan masalah dalam kehidupannya baik didalam maupun diluar sekolah.

Sejalan dengan pernyataan tersebut, Jacob (1982, p.32) menyatakan bahwa "deductive reasoning is a methode of drawing conclusions from facts that we accept as true by using logic". Penalaran deduktif adalah suatu cara penarikan kesimpulan dari pernyataan atau fakta-fakta yang dianggap benar dengan menggunakan logika. Kemampuan penalaran harus dapat didukung dengan pemahaman peserta didik terhadap materi matematika yang dipelajari. Selama proses pembelajaran guru membantu serta memberikan dukungan kepada peserta didik untuk menemukan konsep yang mereka pelajari melalui eksplorasi. Oleh karena itu peserta didik akan lebih memahami konsep-konsep matematika yang sedang mereka pelajari.

Kemampuan pemecahan masalah dan penalaran juga memiliki kaitan yang erat. Fransisco \& Maher (2005, p.362) menyatakan bahwa 
Our perspective of problem solving recognizes the power of children's construction of their own personal knowledge under research conditions that emphasize minimal intervention in the students' mathematical activity and an invitation to students to explore patterns, make conjectures, test hypotheses, reflect on extensions and applications of learned concepts, explain and justify their reasoning and work collaboratively. Such a view regards mathematical learning and reasoning as integral parts of the process of problem solving.

Pemecahan masalah memandang bahwa kekuatan mengkonstruk dari anak melalui pengetahuan mereka sendiri yang menekankan terhadap interfensi dalam kegiatan matematika siswa dan karena hal tersebut maka siswa mampu mengeksplorasi pola, mampu membuat dugaan, menguji hipotesis, merefleksikan ekstensi dan aplikasi dari konsep belajar, menjelaskan dan membenarkan penalaran mereka serta melakukan pekerjaan kolaboratif. Pandangan seperti hal tersebut menganggap bahwa pembelajaran matematika dan penalaran sebagai integral dari proses pemecahan masalah.

Pendapat lain dikemukakan oleh NCTM (Xie, 2010, p.19) yang mengatakan bahwa “developing students' problem-solving ability by exposing them to problem situations, encouraging them to manipulate objects, to use trial and error, inductive reasoning is the major focus, although it does mention deductive reasoning". Perkembangan kemampuan pemecahan masalah siswa mengarahkan mereka pada situasi masalah, mendorong mereka untuk memanipulasi objek, menggunakan trial and error, penalaran induktif yang menjadi fokus utama meskipun penalaran deduktif juga disinggung. MOE (Xie, 2010, p.19) menyatakan bahwa "develop problem-solving and reasoning through instruction, where teachers demonstrate the developing thought process and help students to master underlying mathematical methods and methodologies". Pengembangan pemecahan masalah dan penalaran melalui instruksi dimana guru mendemonstrasikan pengembangannya melalui proses dan menolong siswa untuk menguasai pokok metode matematika dan metodologinya.

Sejalan dengan hal tersebut Xie (2010: p.7) menentukan tujuan untuk mengembangkan penalaran pada siswa seperti yang dinyatakan berikut.
First, students should recognize that reasoning is based on specific assumptions and rules. Second, students should be encouraged to make and investigate conjectures. Conjecture is a great role in reasoning. progression of reasoning skills, beginning with trial-anderror strategies (which are then examined and analyzed) to conjecture strategies. These conjecture exercises are essentially formulating hypotheses about problem solutions and testing them.

Pertama, siswa harus menyadari bahwa penalaran didasarkan pada asumsi dan aturan khusus. Kedua, siswa harus didorong untuk membuat dan menyelidiki dugaan. Dugaan adalah peran besar dalam penalaran. Perkembangan keterampilan penalaran, dimulai dengan strategi trial and error (yang kemudian diperiksa dan dianalisis) untuk menduga strategi. Latihan dugaan ini pada dasarnya merumuskan hipotesis tentang solusi masalah dan menguji mereka.

Berdasarkan pernyataan tersebut dapat disimpulkan bahwa kemampuan pemecahan masalah tidak terlepas dari kemampuan penalaran karena dalam memecahakan masalah yang ada sangat dibutuhkan kemampuan bernalar agar masalah tersebut dapat dipecahkan. Oleh karena itu kemampuan pemecahan masalah dan penalaran dapat diukur bersamaan walaupun kemampuan tersebut memiliki tujuan dan indikator yang berbeda. Melalui penjelasan yang telah dipaparkan maka dapat dilihat pentingnya kemampuan pemecahan masalah dan penalaran matematika diajarkan kepada para peserta didik. Kemampuan pemecahan masalah dan penalaran haruslah dikembangkan sebaik mungkin. Kemampuan pemecahan masalah dan penalaran mirip dengan keterampilan kognitif, sehingga guru harus mengetahui bagaimana mengukurnya. Guru secara teratur menggunakan berbagai praktek penilaian dalam kelas, termasuk pengamatan, diskusi, tugas kinerja, dan penilaian seperti tes pilihan ganda atau jawaban singkat, dan tes uraian (essay). Melihat karakteristik dari pemecahan masalah dan penalaran peserta didik pengukuran yang tepat untuk digunakan adalah dengan memberikan tes uraian (essay). Tes uraian (essay) tersebut dikembangkan dan diharapkan dapat melihat bagaimana kemampuan pemecahan masalah dan penalaran matematika dari setiap peserta didik.

Berdasarkan uraian-uraian sebelumnya, maka yang menjadi tujuan penelitian ini adalah menghasilkan perangkat tes kemampuan pemecahan masalah dan penalaran matematika siswa 
SMP. Harapan dari penelitian ini adalah memberikan sumbangan dalam pembelajaran matematika dan memberikan variasi tes yang telah ada sebelumnya, terutama yang berkaitan dengan tes kemampuan pemecahan masalah dan penalaran siswa SMP dan mengetahui bagaimana kevalidan dan karakteristik dari tes kemampuan pemecahan masalah dan penalaran matematika yang dikembangkan tersebut.

\section{METODE}

Penelitian yang dilaksanakan adalah penelitian dan pengembangan R \& D (Research \& Development). Sesuai dengan redaksi bahwa penelitian ini bertujuan untuk menghasilkan produk. Penelitian ini mengembangkan tes kemampuan pemecahan masalah dan penalaran SMP kelas VIII dari bulan Maret sampai dengan April tahun 2014. Adapun populasinya adalah seluruh siswa Kelas VIII SMP di Yogyakarta Tahun Pelajaran 2013/2014. Setelah memilih secara acak dari keseluruhan siswa, maka dipilih siswa dari tiga sekolah yang memiliki strata tinggi, sedang dan rendah. Setiap sekolah dipilih tiga kelas yang memiliki strata yang berbeda pula. Materi yang dikembangkan dalam penelitian ini adalah materi kelas VIII yang dapat dikembangkan menjadi bentuk tes kemampuan pemecahan masalah dan penalaran matematika.

Produk yang dihasilkan dalam penelitian ini adalah tes kemampuan pemecahan masalah dan penalaran matematika yang mencakup kisikisi dan indikator tes, instrumen tes, rubrik penskoran dan lembar jawaban siswa yang diharapkan akan mampu melihat bagaimana karakteristik tes tersebut dan hasil belajar peserta didik dalam memecahkan masalah dan penalarannya terhadap persolaan matematika. Data yang akan diperoleh dari penelitian ini berupa data validasi ahli mengenai kelayakan instrumen tes yang dikembangkan, data hasil uji coba terbatas (data penilaian siswa terhadap tes yang dikembangkan) dan data hasil uji coba lapangan (data analisis kuantitatif dari tes).

Pengumpulan data melalui instrumen yang terdiri dari tes kemampuan pemecahan masalah dan penalaran matematika berbentuk essay dimana instrumen ini meliputi perumusan kisi-kisi, indikator, sub indikator dan aspek kemampuan, menyusun butir-butir tes, cara penyekoran dan lembar jawaban siswa. Untuk keperluan validasi isi (content validity) terhadap tes kemampuan pemecahan masalah dan penalaran yang dikembangkan dimintakan tanggapan atau respon, saran dan masukkan kepada praktisi dan akademisi dibidang pendidikan matematika dan pengukuran melalui lembar validasi.

Tes kemampuan pemecahan masalah dan penalaran matematika yang dikembangkan terdiri atas materi, Relasi dan Fungsi, Persamaan garis Lurus, Sistem Persamaan Linear Dua Variabel, Lingkaran, Pythagoras dan Bangun Ruang Sisi Datar. Aspek kognitif terdiri atas kemampuan penalaran kemampuan pemecahan masalah. Tes kemampuan pemecahan masalah dan penalaran matematika difokuskan pada persetujuan tentang (1) perumusan indikator, sub indikator dan aspek kemampuan (2) menyusun butir-butir tes (3) cara penyekoran dan (4) lembar jawaban siswa, sehingga keempat yang meliputi pengembangan tes tersebut diukur kevalidannya.

Analisis instrumen tes kemampuan pemecahan masalah dan penalaran matematika dilakukan dengan memvalidkan butir soal, rubrik penskoran dan lembar jawaban siswa dengan lembar kevalidan yang telah disediakan. Sedangkan kevalidan dari kisi-kisi yang mencakup indikator, sub indikator dan aspek kemampuan tidak dianalisis melainkan dari masukan dan saran dari dosen pembimbing dengan berdiskusi.

Analisis data dilakukan untuk mendapatkan bukti penilaian kelayakan instrumen yang akan digunakan dalam mengukur karakteristik tes yang dikembangkan. Analisis lanjutan dari tes tersebut juga dapat digunakan untuk melihat hasil belajar siswa yang mengerjakan tes tersebut. Analisis yang digunakan adalah kesesuaian instrumen dengan teori yang diukur dalam menentukan karakteristik tes yang dikembangkan juga untuk melihat bagaimana hasil belajar siswa setelah mengerjakan tes yang telah dikembangkan. Instrumen yang sudah layak digunakan, dapat digunakan oleh validator. Selanjutnya validator mengukur tingkat kevalidan tes yang dikembangkan. Untuk melihat karakteristik tes dan hasil belajar siswa digunakan peneliti ketika melaksanakan uji coba lapangan.

Data yang telah diperoleh dari para ahli dan praktisi selanjutnya dianalisis untuk menentukan kevalidan produk yang dikembangkan ditinjau dari teoritis dan konsistensi diantara komponen-komponen naskah instrumen tes. Sedangkan data hasil uji coba lapangan digunakan untuk melihat bagaimana karkteristik tes yang dikembangkan dan melihat hasil belajar siswa yang mengerjakan tes yang telah dikembangkan. Langkah-langkah yang digunakan untuk memberikan kriteria kualitas terhadap produk yang dikembangkan sebagai berikut (1) 
data yang berupa skor tanggapan ahli, praktisi (guru) dan siswa yang diperoleh dalam bentuk kategori yang terdiri dari lima pilihan tanggapan tentang kualitas naskah tes yang dikembangkan, yaitu sangat baik (nilai 5), baik (nilai 4), cukup baik (nilai 3), kurang baik (nilai 2) dan tidak baik (nilai 1) diubah menjadi data interval; (2) Data skor yang diperoleh kemudian dikonversi menjadi data kualitatif skala lima, dengan acuan rumus yang dikutp dari acuan rumus yang diadaptasi dari Azwar (2010, p.163) yang ditunjukkan pada Tabel 1.

Tabel 1. Konversi Skor Aktual Menjadi Nilai Skala Lima

\begin{tabular}{ccc}
\hline Nilai & Interval Skor & Kategori \\
\hline A & $X>\bar{X}_{l}+1,5 S b_{i}$ & Sangat \\
& & Setuju \\
B & $\bar{X}_{l}+S b_{i}<X \leq \bar{X}_{l}+1,5 S b_{i}$ & Setuju \\
C & $\bar{X}_{l}-0,5 S b_{i}<X \leq \bar{X}_{l}+S b_{i}$ & Cukup \\
& & Setuju \\
D & $\bar{X}_{l}+1,5 S b_{i}<X \leq \bar{X}_{l}-0,5 S b_{i}$ & Kurang \\
& & Setuju \\
E & $X \leq \bar{X}_{l}-1,5 S b_{i}$ & Tidak \\
& & Setuju \\
\hline
\end{tabular}

$X=$ Total skor aktual

$\bar{X}_{l}=$ Rata-rata skor ideal $=\frac{1}{2}($ Skor maksimum +

Skor minimum)

$S b_{i}=$ Simpangan baku ideal $=\frac{1}{6}($ Skor maksimum -

Skor minimum)

Berdasarkan rumus konversi pada Tabel 1 , diperoleh interval untuk mengkonversi skorskor penilaian dari data kuantitatif ke data kualitatif untuk menentukan kevalidan naskah tes kemampuan pemecahan masalah dan penalaran yang dihasilkan.

Analisis terhadap karakteristik tes yang dihasilkan dilakukan terhadap data hasil tes kemampuan pemecahan masalah dan penalaran yang diperoleh oleh siswa, yang meliputi tes kemampuan pemecahan masalah dan penalaran matematika pada materi lingkaran. Analisis karakteristik tes dilakukan dengan analisis kuantitatif yang dilakukan dengan bantuan Iteman untuk teori tes klasik (Clasiccal Test Theory) dan menggunakan model Rasch untuk teori respon butir (Item Respone Theory) agar dapat dilihat kualitas dan karakteristik tes tersebut. Data yang diproleh dari uji coba lapangan nantinya dianalisis untuk memperoleh kevalidan tes tersebut. Analisis ini dimaksudkan untuk memperoleh informasi tentang indeks kesukaran butir tes dan indeks daya beda butir tes.
Klasifikasi tingkat kesukaran soal dapat dilihat pada Tabel 2 (Nitko, 2011, p.303).

Tabel 2. Tabel Keriteria Indeks Kesukaran

\begin{tabular}{cc}
\hline Daya pembeda & Tafsiran \\
\hline $\mathrm{P}<0,30$ & Soal tergolong sukar \\
$0,30 \leq \mathrm{P} \geq 0,70$ & Soal tergolong sedang \\
$\mathrm{P}>0,70$ & Soal tergolong mudah \\
\hline Indeks daya beda menunjukkan kemam- \\
puan butir soal dapat membedakan antara siswa \\
yang telah menguasai materi yang ditanyakan \\
dan siswa yang tidak/kurang/belum menguasai \\
materi yang ditanyakan. Indeks daya pembeda \\
setiap butir soal biasanya dinyatakan dalam \\
bentuk proporsi. Klasifikasi yang digunakan \\
untuk menentukan daya beda butir adalah \\
seperti pada Tabel 3 (Nitko, 2011, p. 304). \\
Tabel 3. Kriteria Indeks Daya Pembeda Butir \\
\multicolumn{2}{c}{ Soal } \\
\hline Daya \\
pembeda
\end{tabular}

\section{Reliabilitas Tes}

Reliabilitas instrumen berhubungan dengan konsistensi hasil pengukuran, yaitu seberapa konsisten skor dari pengukuran satu kepengukuran berikutnya. Reliabilitas dinyatakan dengan koefisien reliabilitasnya, yaitu koefisien korelasi yang menunjukkan derajat hubungan antara dua hasil pengukuran yang diperoleh dari instrumen atau prosedur yang sama. Reliabilitas merujuk pada ketepatan atau keajegan instrumen tersebut dalam menilai apa yang diinginkan, artinya kapanpun instrumen tersebut digunakan akan memberikan hasil yang relatif sama. Reliabilitas instrumen dianalisis dengan melihat koefisien Alpha Cronbach dengan kriteria minimal 0,65 . Hal ini didukung oleh pendapat Mehrens \& Lehmann (1973, p. 122), yang mengatakan bahwa kriteria minimal koefisien reliabilitas instrumen untuk pengukuran kelompok adalah 0,65 yaitu apabila koefisien alpha $>0,65$ maka instrumen tersebut dinyatakan reliabel.

Analisis item skala dikotomus menurut Rasch Model (RM) dilakukan dengan menggunakan program QUEST. Pengujian untuk penetapan fit tes secara keseluruhan terhadapa model sebagaimana yang dikemukakan oleh Adams \& Khoo (1996, p.30) adalah dengan melihat 
besarnya nilai rata-rata INFIT Mean of Square (Mean INFIT MNSQ) beserta simpangan bakunya atau dengan melihat besarnya nilai rata-rata INFIT $\mathrm{t}$ (Mean INFIT $\mathrm{t}$ ) beserta simpangan bakunya. Bila besarnya nilai rata-rata INFIT MNSQ mendekati 1,0 dengan simpangan baku mendekati 0,0 atau bila besarnya nilai rata-rata INFIT $\mathrm{t}$ (Mean INFIT $t$ ) mendekati 0,0 dengan simpangan baku mendekati 1,0 maka keseluruhan item tes fit dengan model.

Pengujian penetapan fit setiap item dinyatakan terhadap model mengikuti kaidah yang ditetapkan oleh Adams \& Khoo (1996, p.23). Suatu item dinyatakan fit dengan model bila besarnya nilai INFIT MNSQ berada pada kisaran 0,77 sampai 1,30 . Kisaran nilai INFIT MNSQ tersebut membatasi sebaran skor terkalibrasi dan masih berada pada kurva yang berbentuk leptokurtic, yang mencerminkan masih dalam kondisi unity. Item yang tidak fit terhadap model tidak dipakai, sedangkan yang kurang fit (yakni yang memiliki nilai INFIT MNSQ tidak terlalu jauh dari kisaran 0,77 sampai 1,30 ) ditinjau ulang untuk direvisi.

\section{HASIL DAN PEMBAHASAN}

Uji coba produk pengembangan dilakukan di 3 sekolah SMP Negeri Yogyakarta yang memiliki kategori yang berbeda yaitu SMP Negeri 1 Yogyakarta dengan kategori tinggi, SMP Negeri 6 Yogyakarta dengan kategori sedang dan SMP Negeri 14 dengan kategori rendah. Berdasarkan kegiatan uji coba yang dilakukan diperoleh data-data untuk mengetahui kevalidan tes yang dikembangkan. Data diperoleh dari tiga kegiatan uji coba yang dilakukan, yaitu dari kegiatan uji coba ahli/validasi ahli, uji coba terbatas dan uji coba lapangan.

\section{Data Uji Coba Ahli/Validasi Ahli}

Uji coba ahli/validasi ahli dilakukan untuk menilai atau menentukan kevalidan tes yang dihasilkan, serta meminta masukan-masukan atau komentar dari ahli praktisi. Berikut ditunjukkan skor hasil validasi dari tes kemampuan pemecahan masalah dan penalaran matematika yang meliputi instrumen tes, rubrik soal dan lembar jawaban siswa sebagaimana disajikan pada Tabel 4.
Tabel 4. Skor Hasil Validasi Tes Kemampuan Pemecahan Masalah dan Penalaran Matematika

\begin{tabular}{cccc}
\hline \multirow{2}{*}{ Validator } & \multicolumn{3}{c}{ Total skor validasi } \\
\cline { 2 - 4 } & Tes & $\begin{array}{c}\text { Rubrik } \\
\text { Soal }\end{array}$ & $\begin{array}{c}\text { Lembar } \\
\text { Jawaban }\end{array}$ \\
\hline I & 77 & 40 & 40 \\
II & 64 & 31 & 32 \\
III & 77 & 39 & 40 \\
Total & 218 & 110 & 112 \\
Skor & & & \\
Rata-rata & 73 & 37 & 37 \\
Kategori & Valid & Valid & Valid \\
\hline
\end{tabular}

Data Uji Coba Terbatas (Uji Keterbacaan)

Uji coba terbatas dilakukan dengan melibatkan sepuluh orang siswa kelas VIII SMP 7 Yogyakarta yang dipilih berdasarkan kemampuan akademik secara heterogen, yaitu kemampuan tinggi, sedang dan kurang untuk membaca dan mengamati tes kemampuan pemecahan masalah dan penalaran matematika yang dihasilkan. Uji coba dilakukan pada tingkatan kelas yang sama dengan subjek coba penelitian. Dari masing-masing siswa tersebut diminta saran dan masukan-masukan tentang tes atau soal yang mereka baca atau amati. Saran atau masukanmasukan tersebut dijadikan bahan untuk melakukan revisi tes kemampuan pemecahan masalah dan penalaran matematika sebelum digunakan untuk uji coba lapangan.

\section{Data Hasil Uji Coba Lapangan}

Hasil uji coba dianalisis secara empiris atau dianalisis secara kuantitatif untuk melihat kualitas dan karakteristik tes yang telah dihasilkan. Analisis kuantitatif butir soal menggunakan analisis cara klasik (Clasiccal Test Theory) dan teori respons butir (Item Respone Theory) menggunakan Rasch Model dengan program QUEST.

Karakteristik dengan Teori Tes Klasik

Hasil dari perhitungan analisis tingkat kesukaran butir tes disajikan pada Tabel 5 .

Tabel 5. Hasil Analisis Tingkat Kesukaran Butir Soal keseluruhan

\begin{tabular}{ccccc}
\hline No & $\begin{array}{c}\text { Indek } \\
\text { Kesukaran }\end{array}$ & Kriteria & $\begin{array}{c}\text { Butir } \\
\text { Soal }\end{array}$ & Jumlah \\
\hline 1 & $\mathrm{P}>0,70$ & Mudah & - & 0 \\
2 & $0,3 \leq \mathrm{p} \leq$ & Sedang & $1,2,3,4,5$ & 5 \\
3 & 0,70 & Sukar & - & 0 \\
& \multicolumn{2}{c}{ Jumlah } & & 5 \\
\hline
\end{tabular}


Hasil analisis daya pembeda butir soal disajikan pada Tabel 6.

Tabel 6. Hasil Analisis Daya Pembeda Butir Soal

\begin{tabular}{clcc}
\hline No & \multicolumn{1}{c}{ Daya Pembeda } & $\begin{array}{c}\text { Butir } \\
\text { Soal }\end{array}$ & Jumlah \\
\hline 1 & Cukup memuaskan & $1,2,3,4,5$ & 5 \\
2 & $\begin{array}{l}\text { Sedikit atau tanpa revisi } \\
3\end{array}$ & - & 0 \\
& $\begin{array}{l}\text { Perbatasan atau perlu } \\
\text { revisi }\end{array}$ & - & 0 \\
4 & $\begin{array}{l}\text { Dibuang atau revisi } \\
\text { total } \quad \text { Jumlah }\end{array}$ & - & 0 \\
& & 5 \\
\hline
\end{tabular}

Reliabilitas tes kemampuan pemecahan masalah dan penalaran yang diujicobakan sebesar 0,708. Hal ini menunjukkan reliabilitas tes baik karena lebih dari 0,7. Hasil SEM tes kemampuan pemecahan masalah dan penalaran yang diujicobakan sebesar 3,74 yang merupakan estimasi dari standar kesalahan pengukuran dalam perhitungan.

\section{Karakteristik dengan Teori Respon Butir}

Analisis teori respon butir dilakukan dengan skala dikotomus menurut Rasch Model (RM) dilakukan dengan menggunakan program QUEST. Pengujian untuk penetapan fit tes secara keseluruhan terhadap model. Hasil analisis data pengukuran memberikan hasil plot item yang tersaji pada Gambar 1.

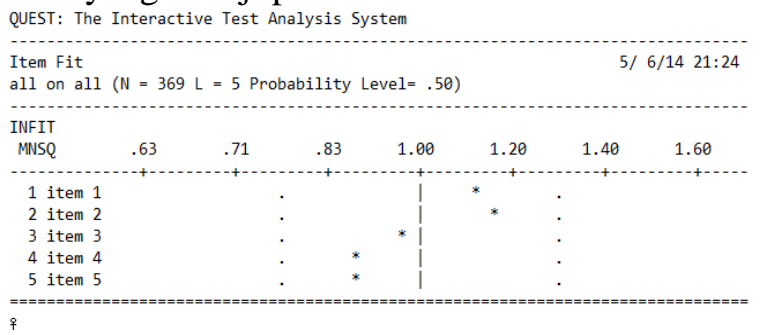

Gambar 1. Plot Item Tes Kemampuan

Pemecahan Masalah dan penalaran Matematika

Batas suatu item dinyatakan fit dengan model jika memiliki INFIT MNSQ diantara 0,77 sampai 1,30. Gambar 1 menunjukkan bahwa seluruh item fit dengan model karena keseluruhan item tercantum di plot dan berada di dalam garis batas bawah INFIT MNSQ. Ringkasan hasil estimasi item dan estimasi testi (person/ case) data testi (N) sebanyak 369 orang dan item (I) sebanyak 5, dengan level peluang sebesar 0,50 menurut Rasch Model (RM) hasil analisis program QUEST disajikan pada Tabel 7. Tabel 7 menunjukkan secara keseluruhan item yang disusun dalam perangkat tes yang diujicobakan fit dengan model. Hal tersebut ditunjukkan oleh besarnya nilai rata-rata Mean MNSQ sebesar sebesar 1,00 dengan simpangan baku sebesar 0,13 memenuhi persyaratan fit statistic dalam program QUEST, yakni mendekati nilai ratarata INFIT MNSQ 1,0 dengan simpangan baku 0,0 . Demikian pula jika dilihat dari besarnya nilai rata-rata INFIT $t-0,02$ dengan simpangan baku 1,03 mendekati persyaratan dalam program QUEST, yakni mendekati nilai rata-rata INFIT t sebesar 0,0 dengan simpangan baku 1,0.

Tabel 7. Hasil estimasi Item (I) dan estimasi Testi (N)

\begin{tabular}{|c|c|c|c|}
\hline No & Uraian & $\begin{array}{c}\text { Estimasi } \\
\text { untuk } \\
\text { item }\end{array}$ & $\begin{array}{c}\text { Estimasi } \\
\text { untuk testi }\end{array}$ \\
\hline 1 & $\begin{array}{l}\text { Nilai rata-rata dan } \\
\text { simpangan baku }\end{array}$ & $0,00 \pm 0,62$ & $-0,02 \pm 0,59$ \\
\hline 2 & \begin{tabular}{lr}
\multicolumn{2}{l}{ Nilai rata-rata dan } \\
simpangan \\
yang & sudah \\
disesuaikan &
\end{tabular} & $0,00 \pm 0,61$ & $-0,02 \pm 0,50$ \\
\hline 3 & Indeks separasi & 0,83 & 0,73 \\
\hline 4 & $\begin{array}{l}\text { Nilai rata-rata dan } \\
\text { simpangan baku } \\
\text { INFIT MNSQ }\end{array}$ & $1,00 \pm 0,13$ & $1,00 \pm 0,80$ \\
\hline 5 & $\begin{array}{l}\text { Nilai rata-rata dan } \\
\text { simpangan baku } \\
\text { Outfit MNSQ }\end{array}$ & $1,01 \pm 0,20$ & $1,01 \pm 0,83$ \\
\hline 6 & $\begin{array}{l}\text { Nilai rata-rata dan } \\
\text { simpangan baku } \\
\text { INFIT t }\end{array}$ & $-0,02 \pm 1,03$ & $-0,07 \pm 1,15$ \\
\hline 7 & $\begin{array}{l}\text { Nilai rata-rata dan } \\
\text { simpangan baku } \\
\text { Outfit t }\end{array}$ & $0,04 \pm 1,19$ & $0,05 \pm 0,93$ \\
\hline
\end{tabular}

Berdasarkan tercapainya kevalidan dan karakteristik yang baik dari naskah tes yang dikembangkan, maka diperoleh suatu produk akhir berupa tes kemampuan pemecahan masalah dan penalaran matematika SMP kelas VIII yang valid dan layak digunakan. Meskipun produk yang dikembangkan valid dan layak digunakan tetapi masih terdapat beberapa keterbatasan yang menjadi kendala dalam pelaksanaan penelitian ini. Berdasarkan atas hal tersebut, maka ada beberapa hal yang disarankan, antara lain: (1) materi yang terbatas pada materi kelas VIII; (2) produk yang dikembangkan terbatas pada tes kemampuan pemecahan masalah dan penalaran matematika; (3) uji coba hanya dilakukan satu tahap, tiga sekolah dan 8 kelas dari ketiga sekolah yang terpilih, walaupun semestinya diperlukan uji coba lanjutan dan sekolah yang lebih banyak; (4) tes kemampuan pemecahan masalah dan penalaran matrmatika yang dihasilkan hanya pada tahap pengembangan, sedangkan tahap 
diseminasi tidak dilaksanakan karena keterbatasan waktu.

\section{SIMPULAN}

Hasil penelitian menunjukkan bahwa perangkat yang dikembangkan memiliki kategori valid. Karakteristik dari tes yang dikembangkan juga memiliki karakteristik yang baik, ditinjau dari tingkat kesulitan tes berada pada kategori sedang dan memiliki daya beda cukup memuaskan. Secara keseluruhan hasil penelitian menunjukkan bahwa tes kemampuan pemecahan masalah dan penalaran matematika yang dikembangkan layak digunakan

\section{DAFTAR PUSTAKA}

Adams, D., \& Hamm, M. (2010). Demystify math, science and technology: Creativity, innovation and problem solving, plymouth. Lenham: Rowman \& Littlefield Education.

Adams, R. J., \& Khoo, Siek-toon. (1996). Quest the interactive test analysis system version 2.1. Melbourne: The Australian Council for Educational Research.

Azwar, S. (2010). Tes prestasi: Fungsi dan pembangunan pengukuran prestasi belajar (edisi kedua).Yogyakarta: Pustaka Pelajar.

Barbey, A. K., \& Barsalou, L. W. (2009). Reasoning an problem solving: models. Atlanta, GA: Elsevier Ltd.

Brodie, K. (2010). Teaching mathematical reasoning in secondary school classroom. New York, NY: Springer Science Business Media, LCC.

Clark, A. (2009). Problem solving in singapore math. Singapore: Houghton Mifflin Harcourt Publisher.

Crocker, L., \& Algina, J. (1986). Introduction to clasical and modern test theory. New York, NY: CBS College Publishing.

Depdiknas. (2006) Peraturan Menteri Pendidikan Nasional RI Nomor 22, Tahun 2006, tentang Standar Isi.

Fransisco, J. M., \& Maher, C.A. (2005). Conditions for promoting reasoning in problem solving: insight from a longitudinal study. Journal of Mathematical Behavior, 24(1), 361-372.

Gronlund, N. E., \& Linn, R. L. (1990). Measurement and evaluation in teaching $\left(6^{\text {th }}\right.$ ed $)$. New York, NY: Macmilan Publishing Company.

Guilford, J. P. (1936). Psychometric methods. New York, NY: Mc Graw Hill Book Company, Inc.

Haylock, D., \& Thangata, F. (2007). Key concepts in teaching primary mathematics. London, UK: SAGE.

Herman, T. (2007). Pembelajaran berbasis masalah untuk meningkatkan kemampuan penalaran matematis siswa SMP. Cakrawala Pendidikan, 1(1), 41-62.

Jacob, H. R. (1982). Mathematics, a human endeavor $\left(2^{\text {nd }} e d\right)$. San Fransisco, CA: W.H. Freeman and Company

Kaur, B. (2009). Reasoning and communication in mathematics classroom - some "what" strategies. Diambil pada tanggal 12 Juli 2013, dari www.mav.vic.edu.au/files/ conferences/2009/16Kaur.pdf.

Keraf, G. (1982). Argumen dan narasi. Komposisi lanjutan III. Jakarta: Gramedia

Lester, F. K. (1980). Research on mathematical problem solving. Reston, VA: National Council of Teacher of Mathematics.

Mardapi, D. (2008). Teknik penyusunan instrumen tes dan non tes. Yogyakarta: Mitra Cendikia.

Mehrens, W.A., \& Lehman, I. (1984). Measurement and evaluation in educational and psychology. New York, NY: Holt Rinehart.

Nitko, A., \& Brookhart, S. (2011). Educational assesment of students $\left(6^{\text {th }} \mathrm{ed}\right)$. Boston, MA: Pearson Education, Inc.

Nunnaly, J. C. (1981). Psychometric theory. New York, NY: McGraw Hill.

Polya, G. (2004) How to solve it: A new aspect of mathematical method. Princenton, NJ: Princenton University Press.

Purwanto. (2007). Instrumen penelitian sosial dan pendidikan. Yogyakarta: Pustaka Belajar

Reynolds, C. R., Livingston, R. B., \& Willson, V. L. (2009). Measurement and assesment in education. Upper Sadle River, NJ: Pearson Education, Inc.

Reys, R., et al. (2009). Helping children learn mathematics $\left(9^{\text {th }}\right.$ ed.). New York, NY: John Wiley \& Sons, Inc. 
Pythagoras, 11 (2), Desember 2016 - 181

Nurul Afni Sinaga

Royer, J. M. (ed.). (2003). Mathematical cognition. Greenwich, CT: Age Publishing, Inc.

Schoenfeld, A. (1992). Learning to think mathematically: Problem solving, metacognition and sense making in mathematics. Dalam D. A. Grouws (Eds.), Handbook of Research on Mathematics Teaching and Learning, New York, NY: Macmillan.

Solso, R. L., et al. (2001). Cognitive psychology $\left(6^{\text {th }}\right.$ ed. $)$. Boston, MA: Allyn and Bacon.
Sternberg, R.B., Been-Zeev, \& Talia. (1996).

The nature of mathematical thinking. Mahwah, NJ: Lawrence Erlbaum Associates.

Xie, Xuehui. (2010). The cultivation of problemsolving and reasoning in NCTM and chinese national standards. Diambil pada tanggal 10 Juli 2013, dari http://www.cimt.plymouth.ac.uk/journal/x uehuixie.pdf 